\title{
"Dit gaan nog belangrik word": Veranderinge in grammatikale toekomsverwysing in Afrikaans "Dit gaan nog belangrik word": Changes in grammatical future reference in Afrikaans
}

\author{
Johanita Kirsten
}

Afrikaanse Taalkunde, Vaaldriekhoekkampus

Noordwes-Universiteit

E-pos: Johanita.Kirsten@nwu.ac.za

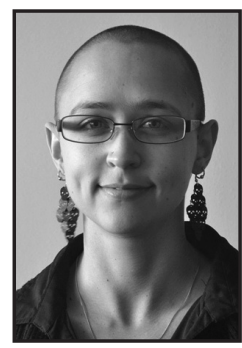

Johanita Kirsten

Johanita Kirsten, senior lektor in Afrikaanse Taalkunde aan die Vaaldriehoekkampus van die Noordwes-Universiteit, se navorsingsbelangstelling fokus op onlangse en voortdurende veranderinge in Afrikaanse taalgebruik. Haar $\mathrm{PhD}$-proefskrif, Grammatikale verandering in Afrikaans van 1911 tot 2010 (2016, NoordwesUniversiteit) onder leiding van prof. Bertus van Rooy (Noordwes-Universiteit), handel oor veranderinge in Afrikaanse tydsaanduiding, voornaamwoorde en die genitief. Sy verken Afrikaans diachronies, deur mikrolinguistiese en ander taalkenmerke se verandering met verloop van tyd verder te ondersoek, aan die hand van gedateerde, elektroniese korpora van KaapsNederlandse en Afrikaanse tekste. Die fokus val veral op grammatikale verandering vanaf die vroeg-twintigste eeu tot die vroeg-een-en-twintigste eeu, maar sluit ook ander tipes taalverandering in.
JohAnita KIRSTEN, senior lecturer in Afrikaans Linguistics at the Vaal Triangle Campus of the North-West University, is interested in recent and ongoing changes in Afrikaans language use. Her $\mathrm{PhD}$-thesis, Grammatikale verandering in Afrikaans van 1911 tot 2010 [Grammatical changes in Afrikaans from 1911 to 2010] under supervision of prof. Bertus van Rooy (North-West University), focuses on changes in Afrikaans temporal reference, pronoun use and the genitive. She investigates Afrikaans diachronically, by tracing changes in micro-linguistic and other linguistic characteristics through time, using dated, electronic corpora of Cape Dutch and Afrikaans. The focus is especially on grammatical changes from the early twentieth century to the early twenty first century, but also includes other types of language change.

\footnotetext{
ABSTRACT

"Dit gaan nog belangrik word": Changes in grammatical future reference in Afrikaans Future reference in Afrikaans can be indicated both grammatically and lexically, similar to other West-Germanic languages such as Dutch and English. The modal auxiliary sal "shall", from Dutch zullen, and the auxiliary gaan "go", from Dutch gaan, are commonly used for future reference in Afrikaans, as well as the futurate present where sentences without explicit use of tense still refer to the future.
} 
The overall frequency of gaan does not show changes in a particular direction since initial standardisation in the early twentieth century, but that does not preclude more subtle changes. The lexical item gaan is used as a main verb on the one hand, but also as two types of auxiliary verbs. The main verb usage includes a concrete reference to movement, as well as a more abstract sense of "being about". The one type of auxiliary usage is as a direct linking verb, and the other as a future auxiliary. While some scholars group these two uses together, there are syntactic and semantic differences that warrant the distinction.

Early in the twentieth century, gaan is still used more frequently as a main verb than as an auxiliary, even if the two types of auxiliary uses are put together. In the early twenty first century, however, the auxiliary uses make up two thirds of the overall usage frequency, with future reference as the most frequent function. This shows a significant increase in the use of gaan for future reference.

On the other hand, the auxiliary sal shows a decline in frequency. An important difference between using sal and gaan for future reference, is that gaan only expresses epistemic future reference, while sal can also express a more participant oriented modality (which may or may not include future reference). When the instances of sal with participant oriented modality are removed from the data set, it becomes clear that gaan is slowly moving in on the epistemic uses of sal. While sal is still the preferred form in the written data, the increasing use of gaan might be even more pronounced in informal spoken language.

The futurate present is also frequently used in Afrikaans, but without tagged corpus data it is difficult to describe in much detail. There is a limited exploration of the instances with future adverbials, and these show a limited increase in usage in the course of the century. Because of the limited extent of the data extraction, these findings remain preliminary.

The spread of a change like this often does not proceed at the same pace in different contexts and text types, which is why it is pertinent to explore how the increase in gaan proceeds in more detail. The data suggest that sal is still a more formal variant than gaan, which spreads at a greater tempo in informal text types. Furthermore, the use of gaan to indicate the immediate future rather than a more remote future, as is the case in Standard Dutch, is not reflected in the data from the 1940s onwards. Other expansions in the use of gaan include being used proportionally more frequently in passive and copula constructions, and not just active constructions with agents performing the verbs. It is also increasingly used in intransitive clauses, and with inanimate objects in the clause. All of these expansions, together with the increase in auxiliary usage, further point to the ongoing grammaticalisation of gaan. As is often the case during grammaticalisation, the grammaticalising construction is used increasingly in contexts where other constructions are the preferred option, and it is possible that at the current rate, gaan might overtake sal in certain contexts, even in formal written Afrikaans.

KEY WORDS: grammaticalisation, grammatical change, temporal reference, future reference, verbs, linking verbs, auxiliary verbs, futurate present, corpus linguistics, historical written Afrikaans

TREFWOORDE: grammatikalisering, grammatikale verandering, tydsaanduiding, toekomsverwysing, werkwoorde, skakelwerkwoorde, hulpwerkwoorde, toekomstige presens, korpuslinguistiek, historiese geskrewe Afrikaans 


\section{OPSOMMING}

Toekomsverwysing in Afrikaans kan grammatikaal en leksikaal aangedui word, soortgelyk aan ander Wes-Germaanse tale soos Nederlands en Engels. Die modale hulpwerkwoord sal, afkomstig van Nederlandse zullen, en die hulpwerkwoord gaan, van Nederlandse gaan, word algemeen gebruik vir toekomsverwysing, asook die toekomstige presens waar sinne sonder tempusaanduiding na die toekoms verwys. Die totale gebruiksfrekwensie van gaan toon nie tekens van verandering sedert standaardisering nie, maar die verskillende gebruike het tog nie stabiel gebly nie. Sedert standaardisering het die sintaktiese en semantiese gebruikskontekste van toekomsverwysende gaan uitgebrei, en waar die leksikale item gaan vroeg in die twintigste eeu nog oorwegend as hoofwerkwoord gebruik is, word dit vandag oorwegend as 'n hulpwerkwoord (direkte skakelwerkwoord en toekomsverwysende hulpwerkwoord) gebruik.

\section{INLEIDING EN KONTEKSTUALISERING}

Daar is heelwat verskillende wyses van toekomsverwysing in die Wes-Germaanse taalfamilie, waarby ' $n$ aantal perifrastiese konstruksies ingesluit is. In Engels, byvoorbeeld, is daar will "wil" en shall "sal", wat dikwels verkort word na 'll, en be going to, wat dikwels verkort word na gonna. Die werkwoord werden "word" word gebruik vir toekomsverwysing in Duits (Hilpert 2008:131), en Nederlands wissel tussen zullen "sal" en gaan (Hilpert 2008:106). Afgesien van hierdie grammatikale toekomsverwysing in Wes-Germaanse tale, is daar ook 'n toekomstige presens (futurate present) (Hilpert 2008:157), waar die presens gebruik word om na die toekoms te verwys. Afrikaans, wat ook 'n lid van die Wes-Germaanse taalfamilie is, gebruik soortgelyke konstruksies vir toekomsverwysing.

Daar is drie verskillende strategieë om na die toekoms te verwys in Afrikaans: (1) met behulp van die modale hulpwerkwoord sal, wat 'n sterk implikasie van toekomsverwysing insluit, afkomstig van Nederlandse zullen; (2) met behulp van die hulpwerkwoord gaan, soortgelyk aan Nederlandse gaan, wat ook as 'n hoofwerkwoord van beweging gebruik word; (3) met behulp van die toekomstige presens.

Op die oog af is daar nie enige opvallende veranderinge in Afrikaanse toekomsverwysing gedurende die afgelope eeu nie, maar korpusdata wys dat daar tog onderliggende voortdurende verandering aan die gang is. Hierdie artikel is 'n beskrywing van hierdie veranderinge, teen die agtergrond van die breër Wes-Germaanse taalfamilie.

Die artikel is soos volg gestruktureer: in die volgende afdeling beskryf ek die metodologie en die korpora wat gebruik word. Daarna volg die analises, eerstens 'n beskrywing van sal, daarna van gaan, met 'n kort beskrywing van die gebruik van die toekomstige presens. Ek vergelyk dan die gebruik van sal met die gebruik van gaan, waarna ek spesifiek fokus op die grammatikalisering van gaan gedurende die afgelope eeu.

\section{METODOLOGIE}

In korpusdata manifesteer taalverandering dikwels deur veranderinge in gebruiksfrekwensie en gebruikskontekste (Biber et al. 1998:209), wat van besondere belang kan wees in grammatikaliseringstudies. Vir die diachroniese bestudering van grammatikalisering in slegs een eeu is meer as een interval besonder nuttig. Voorbeelde van sulke studies is Mair (2006) en Leech et al. (2009), wat gebruik maak van 'n metode genaamd korttermyn diachroniese vergelykende korpuslinguistiek. 'n Belangrike komponent van die metode is dat die verskillende korpora wat gebruik word vergelykbaar is, met ander woorde die samestelling van die korpora moet dieselfde wees behalwe vir die tydperk wanneer die tekste geproduseer is. 
Die empiriese ontwerp van die studie is losweg gebaseer op die model van Mair (2006) en Leech et al. (2009). Elke korpus verteenwoordig 'n dekade van geskrewe taalgebruik: 1911-1920 (korpus \#1), 1941-1950 (korpus \#2), 1971-1980 (korpus \#3) en 2001-2010 (korpus \#4). Daar is min of meer 261000 woorde per korpus met dieselfde aantal woorde vir elke tekstipe, met 'n maksimum van ongeveer 2000 woorde vanuit een teks.

TABEL 1: Korpusbesonderhede

\begin{tabular}{|l|l|c|}
\hline Kategorie & Tekstipe & Woordtelling \\
\hline Fiksie & Romans en kortverhale & \pm 60000 \\
\hline Populêre niefiksie & Biografiese tekste & \pm 20000 \\
& Nuus & \pm 20000 \\
& Informatiewe tekste & \pm 60000 \\
& Religieuse tekste & \pm 30000 \\
\hline Akademiese tekste & Geesteswetenskappe & \pm 30000 \\
\hline Manuskripte & Natuurwetenskappe & \pm 21000 \\
\hline
\end{tabular}

Een kategorie in een van die korpora is onvolledig: die natuurwetenskaplike akademiese tekste in korpus \#1 bestaan uit slegs 9260 woorde. Baie min natuurwetenskaplike tekste uit die 1910 's is in Afrikaans geskryf - as 'n noodmaatreël is daar amper 5000 woorde geneem uit elk van die twee tekste uit daardie tyd wat vandag beskikbaar is. Wanneer ek frekwensies rapporteer, normaliseer ek die frekwensies van korpus \#1 (proporsioneel verhoog asof die korpus so groot is soos die ander) ter wille van vergelykbaarheid.

Die programmatuurpakket WordSmith is gebruik om woordelyste van elk van die korpora op te stel, waaruit al die gebruiksgevalle van sal en gaan onttrek is. As gevolg van die gebrek aan annoteringsprogrammatuur wat historiese Afrikaanse data kan annoteer, was dit nie moontlik om dié gevalle te onttrek waar die toekomstige presens gebruik word nie, aangesien daar nie 'n spesifieke leksikale item is op grond waarvan dit geïdentifiseer kan word nie. Ek beskryf die metode wat ek gebruik het om die toekomstige presens te ondersoek in die relevante afdeling.

Wanneer daar frekwensieveranderinge in die data voorkom, is die statistiese beduidendheid van die veranderinge bereken met behulp van Rayson (2017) se log-waarskynlikheidspakket wat ontwikkel is spesifiek vir korpusdata. Die toets dui aan of die veranderinge toegeskryf kan word aan toeval, en of dit beduidend is. 'n Resultaat van minder as 3.84 is onbeduidend $(p>0,05)$, tussen 3.84 en 6.63 dui ' $n$ lae vlak van beduidendheid aan ( $p$ is tussen 0,01 en 0,05$)$, en hoër as 6.63 word as beduidend gereken $(p<0,01)$ (Rayson 2017).

\section{ANALISES}

\subsection{Sal}

Die hulpwerkwoord sal, wat ontstaan het uit Nederlandse zullen, word gereken as 'n modale hulpwerkwoord (De Stadler 1992:94, Wybenga 1993:21), hoewel dit hoofsaaklik vir toekomsverwysing gebruik word. Die gebruik van sal stem tot 'n mate ooreen met dié van 
Engelse shall en will, wat ook modale hulpwerkwoorde is wat aangewend word vir toekomsverwysing. Soos shall en will, behels die modale funksie van sal aan die een kant agentgeöriënteerde intensie of wilskrag, soos in voorbeeld 1, en epistemiese modaliteit met moontlike toekomsverwysing, geïllustreer in voorbeeld 2.

(1) Ek sal maar my kans afwag. (korpus \#4, Biografiese teks)

(2) Hiertoe sal die volgende beide eksperimente groteliks opklaring verskaf. (korpus \#2, Natuurwetenskappe)

Sal word soms gebruik om epistemiese modaliteit aan te dui sonder toekomsverwysing (Ponelis 1979:249), soos geïllustreer in voorbeeld 3. Die gevalle waar die implikasie van toekomsverwysing ontbreek (slegs 'n handvol), is uit die datastel verwyder aangesien die fokus juis op toekomsverwysing is.

(3) 'n Jongman? O, ja, dit sal Willem du Preez wees, om na die gewel te kom kyk. (korpus \#3, Fiksie)

Die onderskeid tussen die twee algemene kategorieë van modaliteit - agent-geöriënteerd en epistemies - is relevant in die ondersoek van sal in toekomsverwysing. Terwyl intensie of wilskrag natuurlik toekomsverwysing kan impliseer, is epistemiese modaliteit meer objektief en, soos De Stadler (1992:95) uitwys, "suiwerder" toekomsverwysend.

Die onderskeid tussen die twee tipes modaliteit is egter nie eenvoudig of maklik om te tref nie, aangesien intensie spreker-intern is, en sal vir albei tipes modaliteit gebruik word. Ter wille daarvan om 'n betekenisvolle en konsekwente onderskeid tussen die tipes modaliteit te tref (sien Van der Auwera \& Plungian (1998) vir meer detail oor modaliteit), het ek die kriteria in tabel 2 saamgestel.

TABEL 2: Kriteria vir die onderskeid tussen die verskillende modale gebruik van sal

\begin{tabular}{|l|l|l|}
\hline Kategorie & Agent-georiënteerd & Epistemies \\
\hline \multirow{2}{*}{ Semantiese konteks } & $\begin{array}{l}\text { Eksplisiete aanduiding van } \\
\text { persoonlike versekering, } \\
\text { intensie, ens. }\end{array}$ & $\begin{array}{l}\text { Eksplisiete aanduiding van } \\
\text { objektiewe voorspelling }\end{array}$ \\
\cline { 2 - 3 } & Versoeke & Voorwaardes \\
\hline $\begin{array}{l}\text { Meegaande modale } \\
\text { hulpwerkwoorde }\end{array}$ & moet, wil, kan (subjektief) & kan (objektiewe vermoë) \\
\hline Onderwerp van die sin & $\begin{array}{l}\text { Menslike onderwerp } \\
\text { (passief uitgesonder) }\end{array}$ & Enige tipe onderwerp \\
\hline Aard van die hoofwerkwoord & Slegs uitvoer-werkwoorde & $\begin{array}{l}\text { Uitvoer-, ontvang- en statiewe } \\
\text { werkwoorde }\end{array}$ \\
\cline { 2 - 3 } & Emosionele werkwoorde & Enige tipe werkwoorde \\
\hline Betekenis van die negatief & Negativering dui op nie-intensie & Negativering dui op valsheid \\
\hline Pragmatiese konteks & Interpersoonlike tekste & Feitelike tekste \\
\cline { 2 - 3 } & $\begin{array}{l}\text { Interpersoonlike situasies } \\
\text { binne tekste }\end{array}$ & $\begin{array}{l}\text { Oordrag van feitelike } \\
\text { gegewens }\end{array}$ \\
\hline Adjunkte en bywoorde & Dui intensie of verpligting aan & $\begin{array}{l}\text { Dui op moontlikheid of } \\
\text { waarskynlikheid }\end{array}$ \\
\hline
\end{tabular}


Die eerste kategorie van kriteria is semantiese konteks. Wanneer daar eksplisiete aanduidings van intensie of wilskrag is, soos voorbeeld 4, of wanneer'n versoek gerig word, soos voorbeeld 5, word dit as agent-georiënteerd gereken, terwyl eksplisiete aanduidings van objektiewe voorspellings of omstandighede, soos in voorbeeld 6, geneem word as 'n teken van epistemiese modaliteit.

(4) Ons sal graag na u vergadering van 22 Februarie aandag aan die verpligtinge skenk. (korpus \#4, Manuskrip)

(5) Dan sal jij vir mij ook speel? (korpus \#1, Fiksie)

(6) Soos later baie duidelik sal blyk, het hy hiervoor alles feil gehad. (korpus \#2, Biografiese teks)

Wanneer addisionele modale hulpwerkwoorde saam met sal gebruik word, neem ek moet en wil as aanduidings van agent-georiënteerde modaliteit, terwyl kan beide objektiewe vermoë (epistemies) en subjektiewe intensie (agent-georiënteerd) kan uitdruk. Niemenslike sintaktiese onderwerpe word tipies nie met agent-georiënteerde modaliteit gebruik nie, waar menslike onderwerpe saam met albei tipes modaliteit gebruik word.

As die hoofwerkwoord in die klous ' $n$ koppelwerkwoord is, of as dit ' $n$ handeling uitdruk waarin die sintaktiese onderwerp die ontvanger is, soos voorbeeld 7, sluit dit tipies intensie uit. Ander handelingswerkwoorde kan weer met albei soorte modaliteit gebruik word. Emotiewe werkwoorde gaan ook tipies saam met agent-georiënteerde modaliteit, soos in voorbeeld 8 .

(7) Ag, kom bog man, dit sal jou nie dronk maak nie... (korpus \#1, Fiksie)

(8) Dat God ons liefhet netsoos ons is en dat Hy nooit sal ophou. (korpus \#3, Religieuse teks)

Wanneer ' $n$ sin nie in die negatief is nie, kan negativering soms ook nuttig wees om die tipe modaliteit uit te klaar: indien negativering 'n aanduiding van nie-intensie is eerder as valsheid, word dit as agent-georiënteerd gereken. Verder is die pragmatiese konteks ook in ag geneem - interpersoonlike tekste en kontekste is meer geneig om agent-georiënteerde modaliteit te bevat, terwyl feitelike tekste eerder met epistemiese modaliteit geassosieer word. Adjunkte of adverbia wat intensie aandui, soos graag (voorbeeld 4), of objektiewe moontlikheid of waarskynlikheid, soos duidelik (voorbeeld 6), word ook in ag geneem.

In elke geval is al die kriteria gesamentlik in ag geneem ter wille van analises wat so akkuraat en konsekwent moontlik is. Die data bevat ' $n$ klein aantal retoriese vrae, wat uitgesluit is. 'n Opsomming van die analiseresultate van sal volgens modaliteit word in tabel 3 gegee.

TABEL 3: $\quad$ Sal gebruiksgetalle

\begin{tabular}{|l|c|c|c|c|c|c|c|c|}
\hline & \multicolumn{2}{|c|}{ korpus \#1 $^{1}$} & \multicolumn{2}{c|}{ korpus \#2 } & \multicolumn{2}{c|}{ korpus \#3 } & \multicolumn{2}{c|}{ korpus \#4 } \\
\hline agent-georiënteerd & 254 & $23,6 \%$ & 236 & $25,2 \%$ & 220 & $24,4 \%$ & 270 & $31,2 \%$ \\
\hline epistemies & 823 & $76,4 \%$ & 700 & $74,8 \%$ & 683 & $75,6 \%$ & 595 & $68,8 \%$ \\
\hline TOTAAL & $\mathbf{1 0 7 7}$ & & $\mathbf{9 3 6}$ & & $\mathbf{9 0 3}$ & & $\mathbf{8 6 5}$ & \\
\hline
\end{tabular}

In korpus \#1 is die Nederlandse vorme zal, zullen, zult en zil steeds gebruik; vir die doeleindes van hierdie analise word dit as ekwivalente van sal gereken. 
Die totale frekwensie van sal neem met verloop van die eeu beduidend af, ${ }^{2}$ en terwyl die proporsionele verdeling tussen die tipes modaliteit min of meer stabiel bly van korpus \#1 tot \#3, is daar 'n toename in agent-georiënteerde gebruike in korpus \#4. Die frekwensie van epistemiese gebruike neem egter deur die loop van die hele eeu af, waar die gebruiksgetalle in korpus \#4 slegs $72 \%$ is van dié van korpus \#1. Ten spyte van die beduidende afname in frekwensie, ${ }^{3}$ bly die epistemiese gebruik meer as tweederdes van die totale gebruike selfs in korpus \#4. Dit wys dat sal aan die een kant steeds meer gebruik word vir "suiwer" toekomsverwysing, maar aan die ander kant dat juis hierdie tipe gebruik afneem deur die loop van die eeu.

\subsection{Gaan}

Die werkwoord gaan is nog 'n direkte erfstuk van Nederlands. Ten tye van die aanvanklike Nederlandse kolonisering van Suider-Afrika is toekomsverwysende gaan reeds enigsins gebruik in Nederlands, maar dit "was not yet the primary function of gaan with a non-finite verbal complement" (Hilpert 2008:114) in kontinentale Nederlands nie. In 'n ondersoek van kontemporêre Nederlands dui Van Olmen en Mortelmans (2009:363) aan dat al die hulpwerkwoordelike gebruike van gaan slegs $38 \%$ van die totale gebruike uitmaak, wat beteken dat toekomsverwysing steeds 'n sekondêre funksie is in Nederlandse taalgebruik. Dit is nie die geval in Afrikaanse taalgebruik nie, waar gaan tans tot 'n groter mate gegrammatikaliseer is.

Anders as sal wat slegs as hulpwerkwoord gebruik word in Afrikaans, word gaan as beide 'n hoofwerkwoord met konkrete en abstrakte betekenisse gebruik, sowel as twee tipes hulpwerkwoorde - 'n verskynsel in grammatikalisering wat Heine (2003:589) "layering" noem. Gaan kan gebruik word om konkrete beweging aan te dui (voorbeeld 9), om meer abstrakte betekenis uit te druk (voorbeeld 10 en 11), as 'n direkte skakelwerkwoord (voorbeeld 12) en met 'n toekomsverwysende betekenis (voorbeeld 13).

(9) Na 'n rukkie staan hy op en gaan na hul toe; maar eers dro hy sy oë af. (korpus \#1, Geesteswetenskappe)

(10) Met my werk gaan dit redelik goed. (korpus \#2, Manuskrip)

(11) Dit gaan oor sy privaatlewe. (korpus \#2, Informatiewe teks)

(12) Ek dink ook dit is reg dat jy hulle gaan haal. (korpus \#3, Fiksie)

(13) Dit gaan egter nie maklik wees nie. (korpus \#4, Manuskrip)

Ponelis (1979:244) onderskei nie tussen die twee verskillende tipes hulpwerkwoorde nie - hy hanteer die hulpwerkwoordfunksies van gaan as 'n "direkte skakelwerkwoord" wat toekomsverwysing kan insluit maar dit nie noodwendig doen nie. Carstens (1998) bespreek Afrikaanse hulpwerkwoorde ooreenkomstig familieverwantskappe en grammatikalisering, en identifiseer verskeie morfosintaktiese eienskappe waarvolgens Afrikaanse hulpwerkwoorde volgens vlakke van grammatikalisering ingedeel kan word (Carstens 1998:77). Terwyl Carstens slegs een inskrywing vir gaan het, wat beteken dat sy ook nie twee tipes hulpwerkwoordgebruike aandui nie, is sommige van haar onderskeidende kenmerke nuttig om die twee gebruike uitmekaar te ken. Hulpwerkwoorde wat minder gegrammatikaliseer is sal wegskuif om ruimte te laat vir 'n meer gegrammatikaliseerde hulpwerkwoord om die V2 posisie in te neem, terwyl die minder gegrammatikaliseerde hulpwerkwoord na die einde van die sin skuif saam met die hoofwerkwoord, soos in voorbeeld 14, of die meer gegrammatikaliseerde hulpwerkwoord volg soos in voorbeeld 15 .

$\begin{array}{ll}2 & \text { Log-waarskynlikheid vir die vier korpora opeenvolgend: } 21.56 \\ 3 & \text { Log-waarskynlikheid vir die vier korpora opeenvolgend: } 32.44\end{array}$

Tydskrif vir Geesteswetenskappe, Jaargang 58 No. 2: Junie 2018

doi.10.17159/2224-7912/2018/v58n2a5 
(14 Pa het al die werksmense gaan roep. (korpus \#3, Fiksie)

(15) Nee wat, Grahamstad kan gaan slaap. (korpus \#4, Fiksie)

Voorbeeld 14 illustreer 'n ander belangrike verskil tussen gaan as skakelwerkwoord en as toekomsverwysende hulpwerkwoord, aangesien die skakelwerkwoord in 'n sin met verledetydsverwysing gebruik word saam met die (meer gegrammatikaliseerde) hulpwerkwoord het, wat die V2 posisie inneem. Terwyl die grens tussen die twee tipes hulpwerkwoordgebruike nie noodwendig duidelik is nie, soos wat dikwels die geval is met verskillende gebruike van dieselfde item (Carstens 1998:78), is die onderskeid sover moontlik behou. Wanneer dit onduidelik was of 'n spesifieke geval 'n skakelwerkwoord of 'n toekomsverwysende werkwoord is, is die sin geherformuleer om te bepaal of dit in die verlede tyd geplaas kan word (in welke geval dit 'n skakelwerkwoord is, soos 14). Alternatiewelik is ander hulpwerkwoorde by die sin gevoeg - as gaan in die V2 posisie bly is dit as 'n toekomsverwysende hulpwerkwoord gereken (soos 16, met die skakelwerkwoord kom), maar as die modale hulpwerkwoord die onderwerp volg, is dit as 'n skakelwerkwoord geklassifiseer (soos 15).

(16) Hulle het gesê ons gaan in die Kaap kom sukkel. (korpus \#3, Informatiewe teks) Tabel 4 gee die gebruiksfrekwensies van die verskillende kategorieë van gaan in die korpusdata.

TABEL 4: $\quad$ Gaan gebruiksgetalle

\begin{tabular}{|c|c|c|c|c|c|c|c|c|c|c|c|c|}
\hline & \multicolumn{3}{|c|}{ korpus $\# 1^{4}$} & \multicolumn{3}{|c|}{ korpus \#2 } & \multicolumn{3}{|c|}{ korpus \#3 } & \multicolumn{3}{|c|}{ korpus \#4 } \\
\hline $\begin{array}{l}\text { beweging } \\
\text { hww. }\end{array}$ & 230 & $35 \%$ & \multirow{2}{*}{$62 \%$} & 178 & $33 \%$ & \multirow{2}{*}{$58 \%$} & 196 & $29 \%$ & \multirow{2}{*}{$45 \%$} & 103 & $16 \%$ & \multirow{2}{*}{$33 \%$} \\
\hline abstrak hww. & 174 & $27 \%$ & & 137 & $25 \%$ & & 109 & $16 \%$ & & 110 & $17 \%$ & \\
\hline skakelww. & 186 & $29 \%$ & \multirow{2}{*}{$38 \%$} & 145 & $27 \%$ & \multirow{2}{*}{$42 \%$} & 240 & $35 \%$ & \multirow{2}{*}{$55 \%$} & 201 & $31 \%$ & \multirow{2}{*}{$67 \%$} \\
\hline $\begin{array}{l}\text { toekoms } \\
\text { hulpww. }\end{array}$ & 61 & $9 \%$ & & 81 & $15 \%$ & & 139 & $20 \%$ & & 229 & $36 \%$ & \\
\hline TOTAAL & 652 & & & 541 & & & 684 & & & 643 & & \\
\hline
\end{tabular}

Tabel 4 wys dat, terwyl die totale frekwensie van gaan fluktueer sonder duidelike tekens van verandering, die verskillende gebruike van gaan wel veranderinge ondergaan. Indien die twee hoofkategorieë van gebruik, naamlik leksikale (hoof)werkwoorde en grammatikale (hulp) werkwoorde, vergelyk word, wys dit dat die hoofwerkwoordgebruik die grootste kategorie is aan die begin van die eeu, waarna die hulpwerkwoordgebruik toeneem tot die hoofgebruik teen die einde van die eeu. Die prototipiese gebruik van gaan skuif dus van leksikaal na grammatikaal. Die kategorieë wat die meeste verander is die konkrete bewegingswerkwoorde en die toekomsverwysende hulpwerkwoorde. Bewegingswerkwoorde is die grootste kategorie in korpus \#1, meer as 'n derde van die totale gebruike, maar daarna krimp dit om die kleinste kategorie in korpus \#4 te wees - 'n baie beduidende verandering. ${ }^{5}$ Die toekomsverwysende

In korpus \#1 is die Nederlandse vorm gaat nog gebruik; vir die doeleindes van hierdie analise word dit as 'n ekwivalent van gaan gereken.

Log-waarskynlikheid vir die vier korpora opeenvolgend: 56.01 
kategorie is die kleinste in korpus \#1, en die grootste kategorie in korpus \#4 - nog 'n beduidende verandering. ${ }^{6}$ Hierdie tendense wys dat, ten spyte van die stabiliteit van die totale gebruiksfrekwensie van gaan, die interne proporsies van die verskillende kategorieë 'n duidelike trajek van grammatikalisering toon. In korpus \#4 maak die mees grammatikale gebruik as toekomsverwysende hulpwerkwoord die grootste proporsie van al die kategorieë uit. Die verhouding tussen leksikale en grammatikale gebruike van gaan word in figuur 1 geïllustreer.

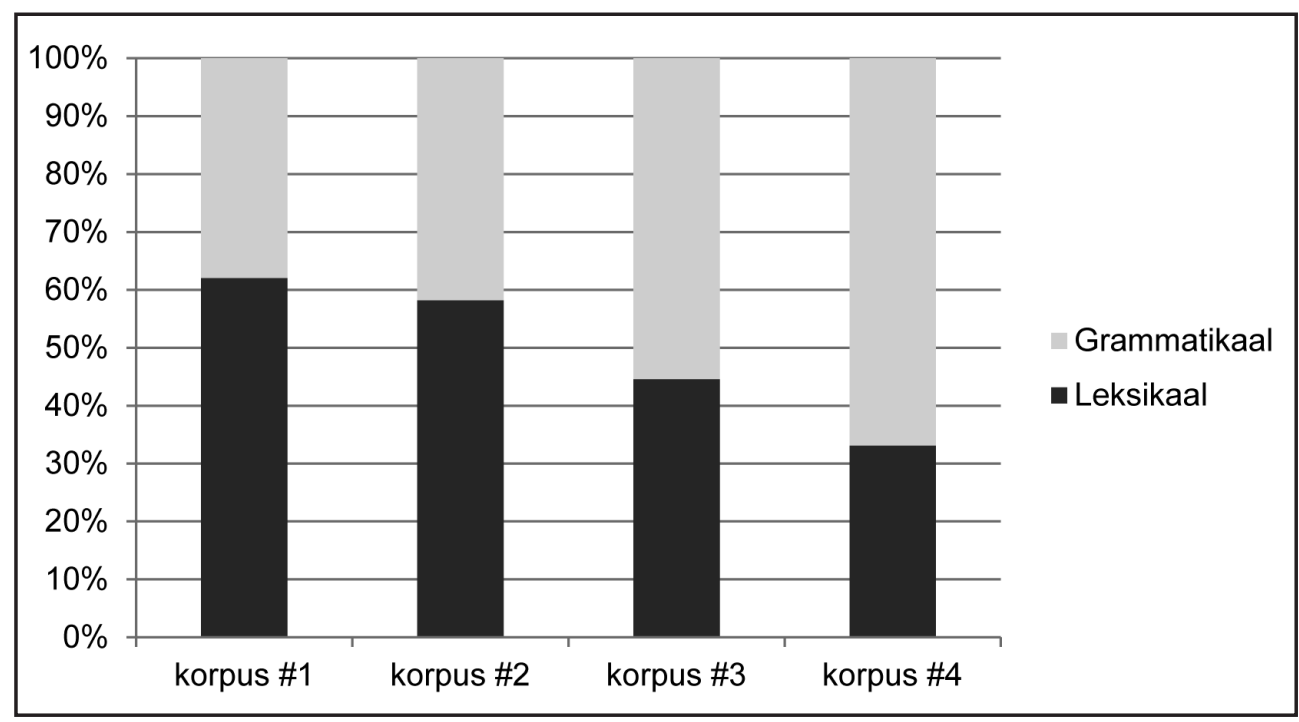

Figuur 1: $\quad$ Die leksikale en grammatikale gebruike van gaan

\subsection{Die toekomsverwysende presens}

Buiten grammatikale toekomsverwysing of tempus, hetsy deur infleksie of hulpwerkwoorde, maak al die Germaanse tale gebruik van die presens om na die toekoms te verwys (Hilpert 2008:157). In sommige Germaanse tale is die toekomstige presens selfs algemener as grammatikale toekomsverwysing (Hilpert 2008:7-8). Dit beteken dat 'n ondersoek na toekomsverwysing in Afrikaans nie die toekomstige presens kan ignoreer nie.

Daar is egter ' $n$ struikelblok in die bestudering van die toekomstige presens in Afrikaanse korpora, hoofsaaklik op grond van die gebrek aan annotering soos wat reeds in afdeling 2 uitgewys is. Dit is dus nie moontlik om al die sinne in die presens te onttrek en vas te stel hoeveel in werklikheid na die toekoms verwys nie. Gelukkig verskaf Hilpert (2008) 'n alternatiewe metode vir die bestudering van die toekomstige presens in korpusdata.

In navolging van Hilpert (2008:158), word die toekomstige presens (eng) gedefinieer as 'n werkwoordkonstruksie in die presens, in 'n matrikssin van 'n sin wat na die toekoms verwys. Dit sluit sekere sinne uit wat soms by die toekomstige presens ingesluit word, soos sintakties onderskikkende werkwoordkonstruksies, voorbeelde met modale werkwoorde, en imperatiewe (Hilpert 2008:158). Vir analisedoeleindes het ek Hilpert (2008:160) verder nagevolg deur te

$6 \quad$ Log-waarskynlikheid vir die vier korpora opeenvolgend: 127.72 
fokus op gevalle "that unambiguously encode future time reference" - sinne met toekomsverwysende adverbiale konstruksies soos more of volgende jaar. ${ }^{7}$ Die voorbeelde is tydens analise in drie groepe verdeel: (1) die toekomstige presens; (2) sinne wat sal of gaan saam met die adverbia gebruik; en (3) die sinne wat in werklikheid nié na die toekoms verwys nie, en nie by verdere analises ingesluit is nie.

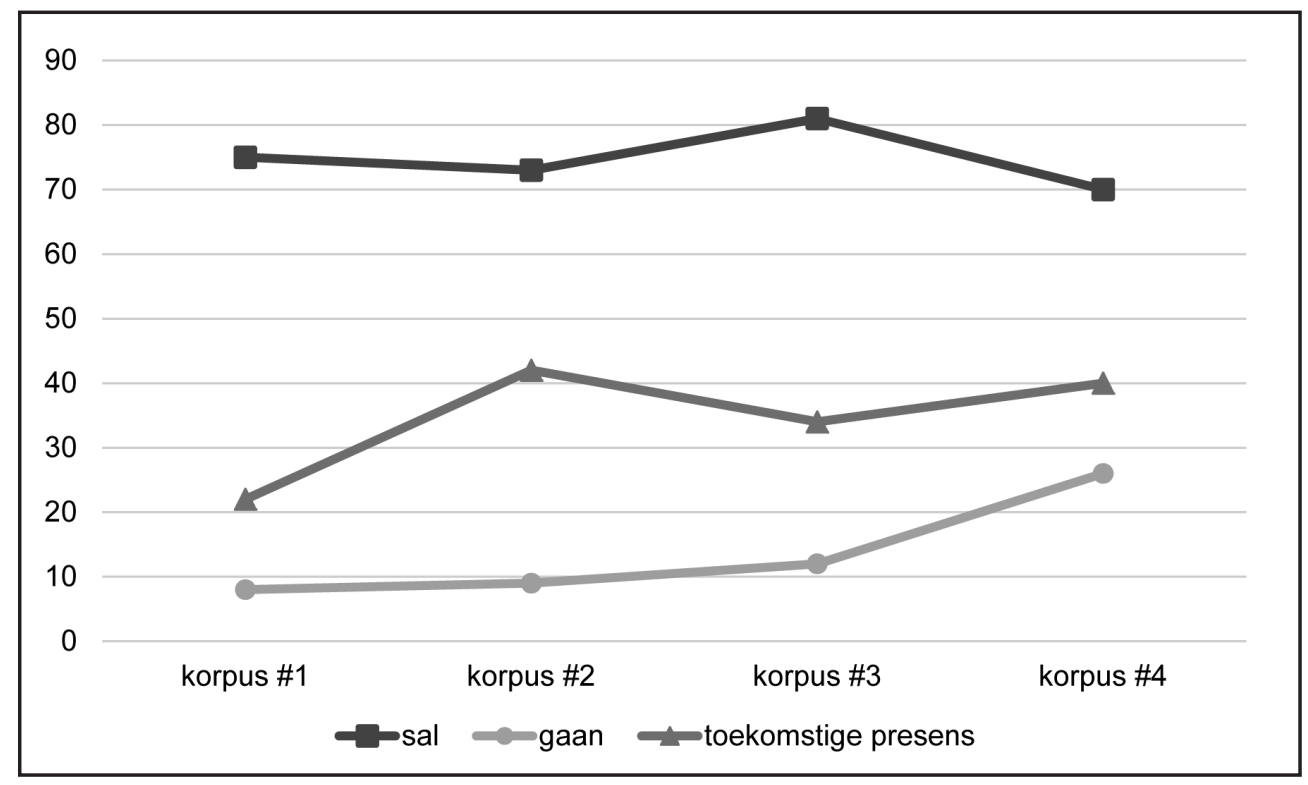

Figuur 2: $\quad$ Die gebruik van sal, gaan en die toekomstige presens in 'n spesifieke datastel

In sekere Germaanse tale soos Duits en Nederlands is die gebruiksfrekwensie van die toekomstige presens hoër as ander toekomsverwysende konstruksies (Hilpert 2008:157). Dit blyk egter nie die geval te wees vir Afrikaans nie. In al die sinne wat met behulp van toekomsverwysende adverbia onttrek is, is óf sal óf gaan in meer sinne teenwoordig as afwesig. Terwyl die gebruik van toekomsverwysende gaan saam met adverbia dieselfde patroon van toename wys as daarsonder, is dit in hierdie datastel steeds minder frekwent as die toekomstige presens.

Ongelukkig is die datastelle redelik klein, met stelle tussen 22 en 42 toekomstige presense per korpus. Sinne met sal in dieselfde datastelle wissel tussen 70 en 81, en sinne met gaan tussen 8 en 26. Die klein datastelle verleen dit ongelukkig nie tot verdere analises nie.

\subsection{Vergelyking: sal en gaan}

In hierdie studie se data toon die epistemiese toekomsverwysende gebruike van sal en gaan teenoorgestelde patrone, en hierdie afdeling gee aandag aan die verhouding tussen hierdie twee gebruike.

$7 \quad$ Ek het Hilpert se lys Engelse adverbia gebruik as 'n riglyn, en verdere voorbeelde wat eie is aan Afrikaans bygevoeg. Die lys sluit al die name van dae en maande in, sowel as 'n lys spesifieke soekterme: binnekort, dag, dekade, eendag, eeu, jaar, komende, later, maand, millennium, more, oor [in frases soos oor ' $n$ week], oormore, toekoms, tyd, uur, vanaand, vanmiddag, vanmore / vanoggend, vannag, volgende en meervoude waar van toepassing. Alle duplikate is verwyder. 
Dit is reeds vroeër uitgewys dat sal in die eerste plek 'n modale hulpwerkwoord is, wat dikwels gebruik word met implisiete toekomsverwysing. Die gebruik van gaan staan in kontras hiermee - selfs wanneer dit soms as 'n merker van sekerheid gebruik word, bly dit in die eerste plek 'n toekomsverwysende hulpwerkwoord (De Stadler 1992:92). Volgens Ponelis (1979:244) het gaan 'n sterker feitelike konnotasie as sal, en kan dit geparafraseer word met "sal beslis". Dit is op grond hiervan dat De Stadler (1992:95) beweer dat gaan 'n "suiwerder" toekomsverwysing bevat as sal. Die analises in hierdie studie bevestig hierdie bewering, aangesien gaan nie met agent-georiënteerde modaliteit gebruik word nie, maar vir objektiewe epistemiese voorspellings van die toekoms. Die beste manier om die verskil te illustreer is met behulp van vrae. Voorbeeld 17a is 'n vraag uit korpus \#4, wat in $17 \mathrm{~b}$ geparafraseer word met gaan in die plek van sal.

(17) a. Sal jy my leer toor, Arboreta? (korpus \#4, Fiksie)

(17) b. Gaan jy my leer toor, Arboreta?

Terwyl 17a 'n versoek is, vra $17 \mathrm{~b}$ nie oor intensie nie maar moontlikheid of waarskynlikheid. Dit beteken dat die toekomsverwysende gebruik van gaan nie in kompetisie is met agentgeoriënteerde sal nie, maar slegs epistemiese toekomsverwysende sal. Tabel 5 gee die gebruiksgetalle van gaan en sal met epistemiese toekomsverwysing.

TABEL 5: $\quad$ Gaan en sal in epistemiese toekomsverwysing

\begin{tabular}{|l|c|c|c|c|c|c|c|c|}
\hline & \multicolumn{2}{|c|}{ korpus \#1 } & \multicolumn{2}{c|}{ korpus \#2 } & \multicolumn{2}{c|}{ korpus \#3 } & \multicolumn{2}{c|}{ korpus \#4 } \\
\hline gaan & 61 & $6,8 \%$ & 81 & $10,2 \%$ & 139 & $16,7 \%$ & 229 & $27,4 \%$ \\
\hline sal & 829 & $93,2 \%$ & 713 & $89,8 \%$ & 691 & $83,3 \%$ & 606 & $72,6 \%$ \\
\hline TOTAAL & $\mathbf{8 9 0}$ & & $\mathbf{7 9 4}$ & & $\mathbf{8 3 0}$ & & $\mathbf{8 3 5}$ & \\
\hline
\end{tabular}

Terwyl sal steeds algemener gebruik word vir epistemiese toekomsverwysing as gaan in geskrewe Afrikaans, is daar 'n voortdurende, beduidende groei in die gebruik van gaan vir dieselfde funksie. Figuur 3 illustreer hierdie verhouding.

Uit tabel 5 en figuur 3 word dit duidelik dat, hoewel die totale frekwensie van epistemiese toekomsverwysing met behulp van hulpwerkwoorde relatief stabiel bly, sal tog besig is om plek te maak vir gaan. Verskynsels met 'n toename in frekwensie versprei egter dikwels nie teen dieselfde tempo en op dieselfde maniere in verskillende kontekste nie. Verdere ondersoek is dus nodig.

Die korpora van hierdie studie is te klein om die data sinvol op te deel op grond van die verskillende tekstipes. Daar is wel aanduidings dat gaan minder formeel is as sal (Müller 2003:85), en om te bepaal hoe formaliteit die verspreiding van gaan beïnvloed, het ek die data in drie vlakke van formaliteit opgedeel: die formele kategorie sluit sakebriewe en akademiese tekste in, die informele kategorie sluit persoonlike briewe en dagboekinskrywings in, en die ander gevalle maak die neutrale kategorie uit. Daarna het ek die frekwensie van gaan per 10000 woorde bereken vir elk van die kategorieë, wat in figuur 4 aangedui word. 


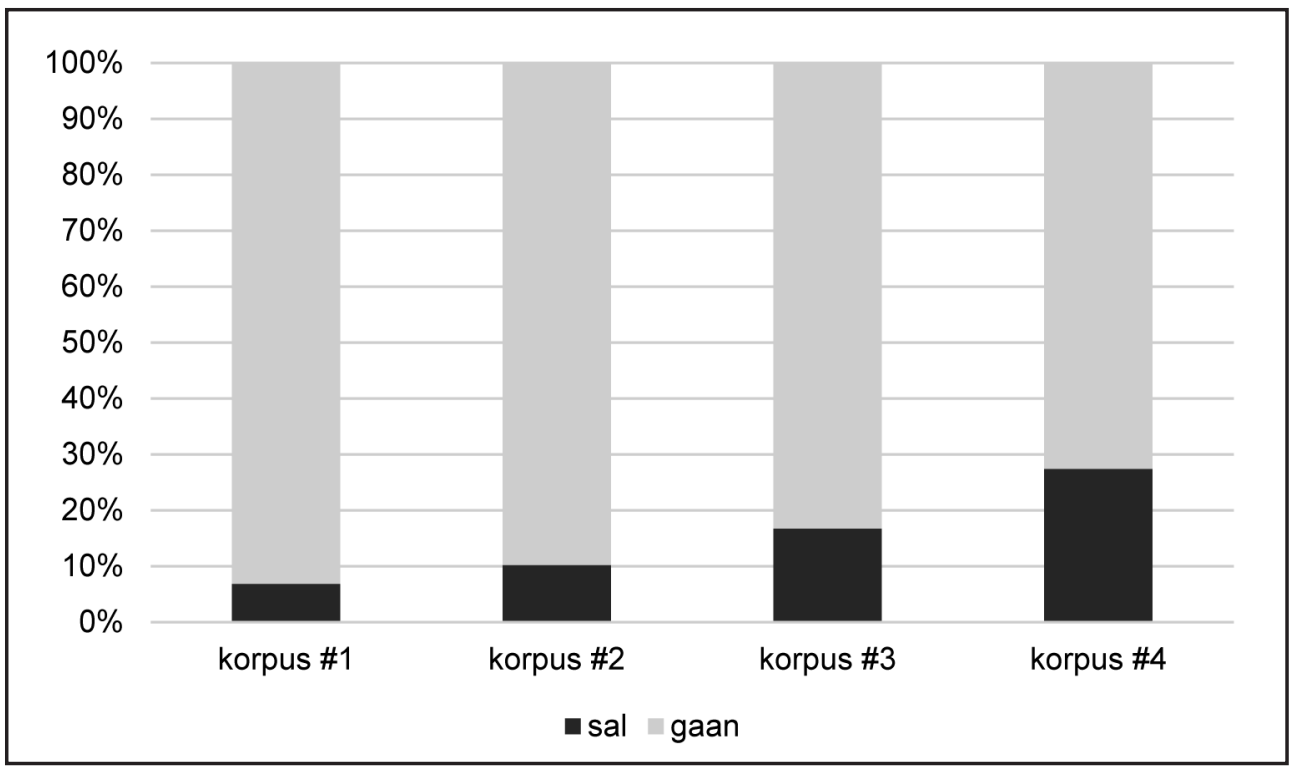

Figuur 3: $\quad$ Die verhouding tussen sal en gaan in epistemiese toekomsverwysing



Figuur 4: $\quad$ Gebruike per 10000 woorde van sal en gaan volgens formaliteit

Figuur 4 wys dat, hoewel die frekwensie van gaan styg in al drie kategorieë van korpus \#2 af, die grootste toename in informele tekste plaasvind. ${ }^{8} \mathrm{Sal}$ is wisselvalliger, maar in breë trekke wys dit die grootste afname in informele tekste. ${ }^{9}$

Log-waarskynlikheid vir die vier korpora opeenvolgend: 28.43

Log-waarskynlikheid vir die vier korpora opeenvolgend: 40.51 
Ter bepaling van verdere moontlike verskille in nuanse tussen sal en gaan is verdere (subtiele of overte) onderskeid tussen verwysing na die onmiddellike of die verre toekoms. In Nederlands verwys gaan meer tipies na die onmiddellike toekoms, terwyl zullen eerder na die verre toekoms verwys (Hilpert 2007:170) en daar kan 'n soortgelyke onderskeid in Afrikaans wees. Tabel 6 rapporteer die gebruiksgetalle van beide gaan en sal met spesifiek onmiddellike toekomsverwysing, soos in voorbeeld 18, of met spesifiek verre toekomsverwysing, soos in voorbeeld 19. Die persentasie is die proporsie wat dit uitmaak van die totale gebruik van elk van die items met epistemiese toekomsverwysing.

(18) Hierdie twee hooftipes van investering sal vervolgens afsonderlik gedefinieer word. (korpus \#3, Geesteswetenskappe)

(19) Die een wat jy eendag gaan koop. (korpus \#3, Fiksie)

TABEL 6: Die gebruik van sal en gaan vir onmiddellike en verre toekoms

\begin{tabular}{|l|c|c|c|c|c|c|c|c|}
\hline & \multicolumn{2}{|c|}{ korpus \#1 } & \multicolumn{2}{c|}{ korpus \#2 } & \multicolumn{2}{c|}{ korpus \#3 } & \multicolumn{2}{c|}{ korpus \#4 } \\
\hline gaan onmiddellik & 15 & $24,6 \%$ & 8 & $9,9 \%$ & 28 & $20,1 \%$ & 36 & $15,7 \%$ \\
\hline gaan ver & 0 & - & 2 & $2,5 \%$ & 7 & $5 \%$ & 10 & $4,4 \%$ \\
\hline sal onmiddellik & 10 & $1,2 \%$ & 26 & $3,6 \%$ & 20 & $2,9 \%$ & 42 & $6,9 \%$ \\
\hline sal ver & 38 & $4,6 \%$ & 15 & $2,1 \%$ & 12 & $1,7 \%$ & 22 & $3,6 \%$ \\
\hline
\end{tabular}

Tabel 6 wys dat die Nederlandse onderskeid tot ' $n$ mate teenwoordig is in korpus \#1, maar die daaropvolgende korpora wys dat gaan toenemend na die verre toekoms verwys, ${ }^{10}$ terwyl sal ook meer na die onmiddellike toekoms eerder as die verre toekoms verwys vanaf korpus \#2. Die data wys verder dat beide gaan en sal meestal gebruik word sonder spesifieke aanduidings van die nabyheid of afstand van die toekoms waarna dit verwys.

\subsection{Voortdurende grammatikalisering van gaan}

Ander moontlike aanduidings van die grammatikalisering van toekomsverwysende gaan kan gevind word in die werkwoordkonstruksies waarin dit gebruik word, sowel as die tipe sintaktiese onderwerpe waarmee dit gebruik word. Hilpert (2007:179) wys dat in kontemporêre Nederlands, gaan eerder saam met onoorganklike aktiwiteite en onderwerpe met lae agentiwiteit gebruik word.

Wat die tipe werkwoordkonstruksie betref, word daar onderskei tussen aktiewe, passiewe en kopulakonstruksies. Figuur 4 wys dat die proporsie aktiewe konstruksies krimp tussen korpus \#1 en \#2, asook tussen korpus \#3 en \#4. Die proporsie gebruike saam met kopulakonstruksies fluktueer ná beduidende groei tussen korpus \#1 en \#2. ${ }^{11}$ Die proporsie passiefkonstruksies met toekomsverwysende gaan groei deurlopend, wat verdere uitbreiding in die gebruikskontekste van gaan aandui.

10 Log-waarskynlikheid vir die vier korpora opeenvolgend: 5.75 (lae vlak van beduidendheid)

11 Log-waarskynlikheid vir die groei van korpus \#1 tot \#2: 12.05 


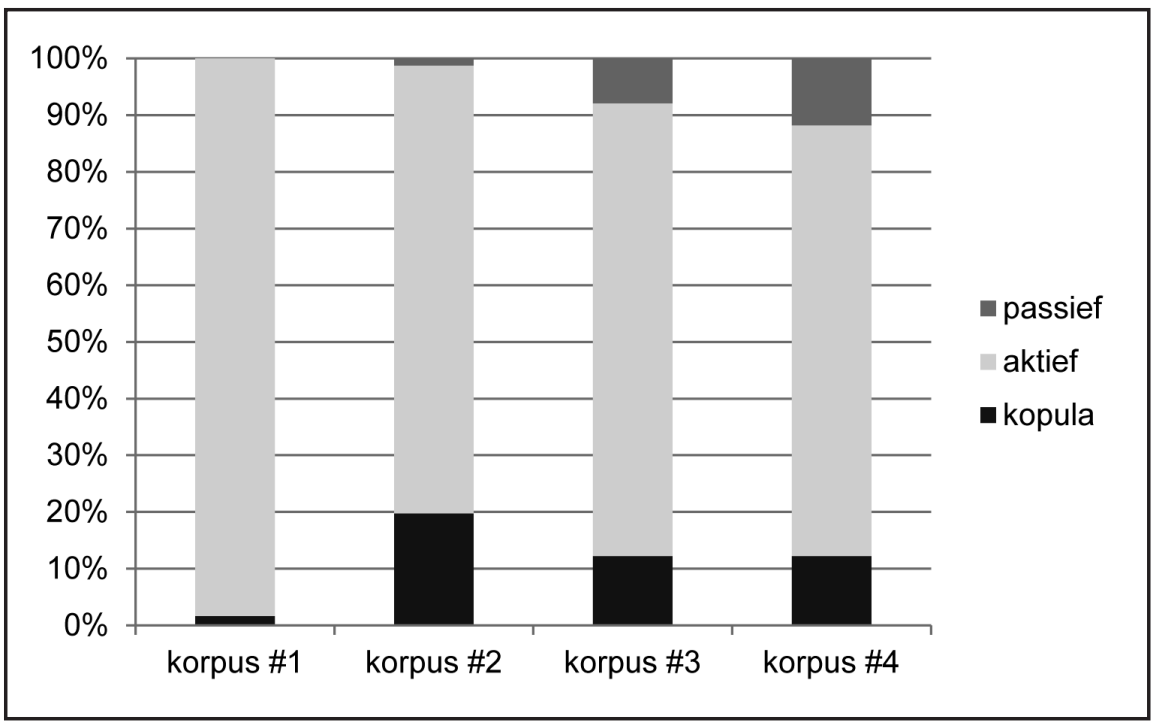

Figuur 5: $\quad$ Tipes werkwoordkonstruksies waarin toekomsverwysende gaan gebruik word

Wat oorganklikheid betref, dui Hilpert (2008:111) aan dat Nederlandse gaan tipies eerder met onoorganklike werkwoorde gebruik word. In kontras daarmee, soos in figuur 5 aangedui word, word Afrikaanse toekomsverwysende gaan meer in oorganklike konstruksies gebruik.

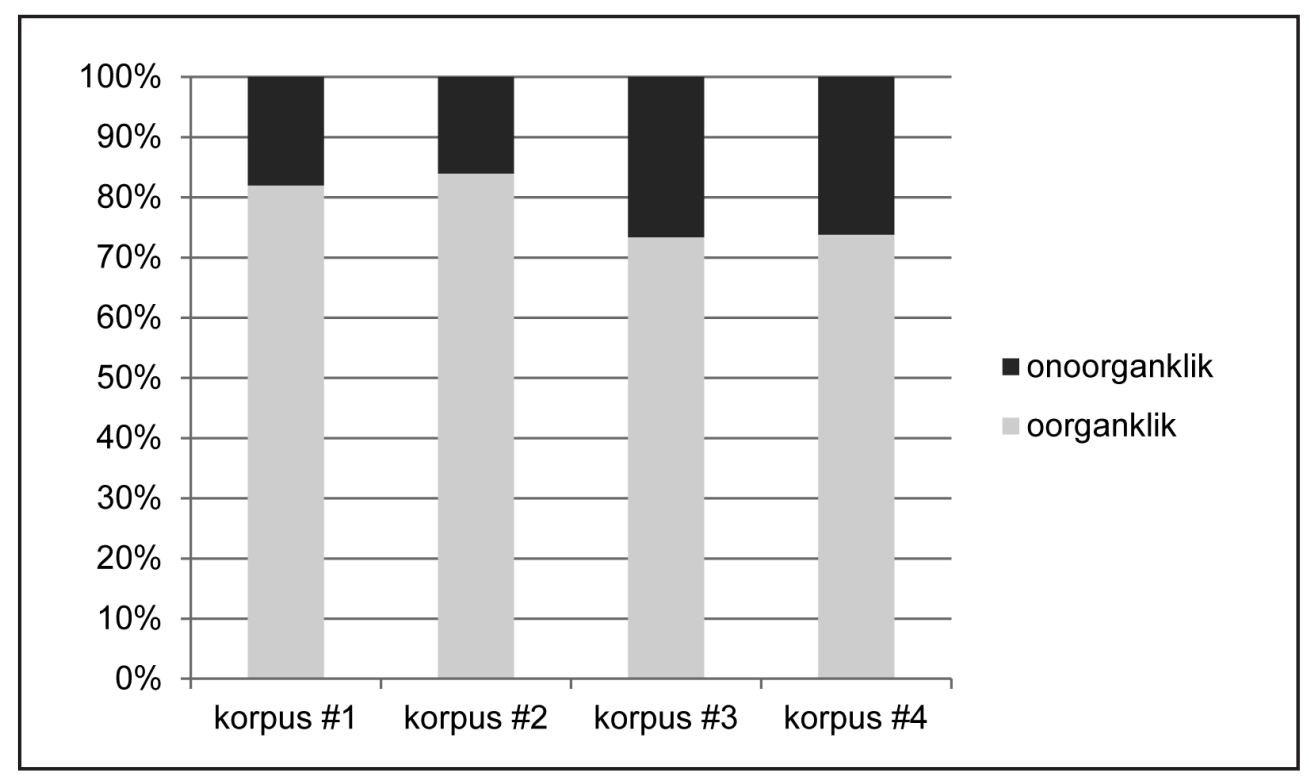

Figuur 6: $\quad$ Die gebruik van gaan in oorganklike en onoorganklike konstruksies 
In die proses van grammatikalisering vanaf 'n bewegingswerkwoord na toekomsverwysing, vind daar dikwels 'n verskuiwing van gebruik saam met menslike onderwerpe na gebruik saam met onderwerpe wat nie kan beweeg of intensies hê nie (Poplack \& Tagliamonte 2000:332). Figuur 6 wys dat die proporsie gebruike saam met sielhebbende ("animate") onderwerpe krimp deur die loop van die eeu, met 'n statisties beduidende groei van siellose ("inanimate") onderwerpe ooreenkomstig getal en proporsie. ${ }^{12}$ Van korpus \#2 af verder is die proporsie siellose onderwerpe wat saam met toekomsverwysende gaan gebruik word deurlopend hoër as die gebruik saam met hoofwerkwoord-gaan en skakelwerkwoord-gaan. Dit dui 'n toenemende buigsaamheid aan in die tipes kontekste waarin toekomsverwysende gaan gebruik word.

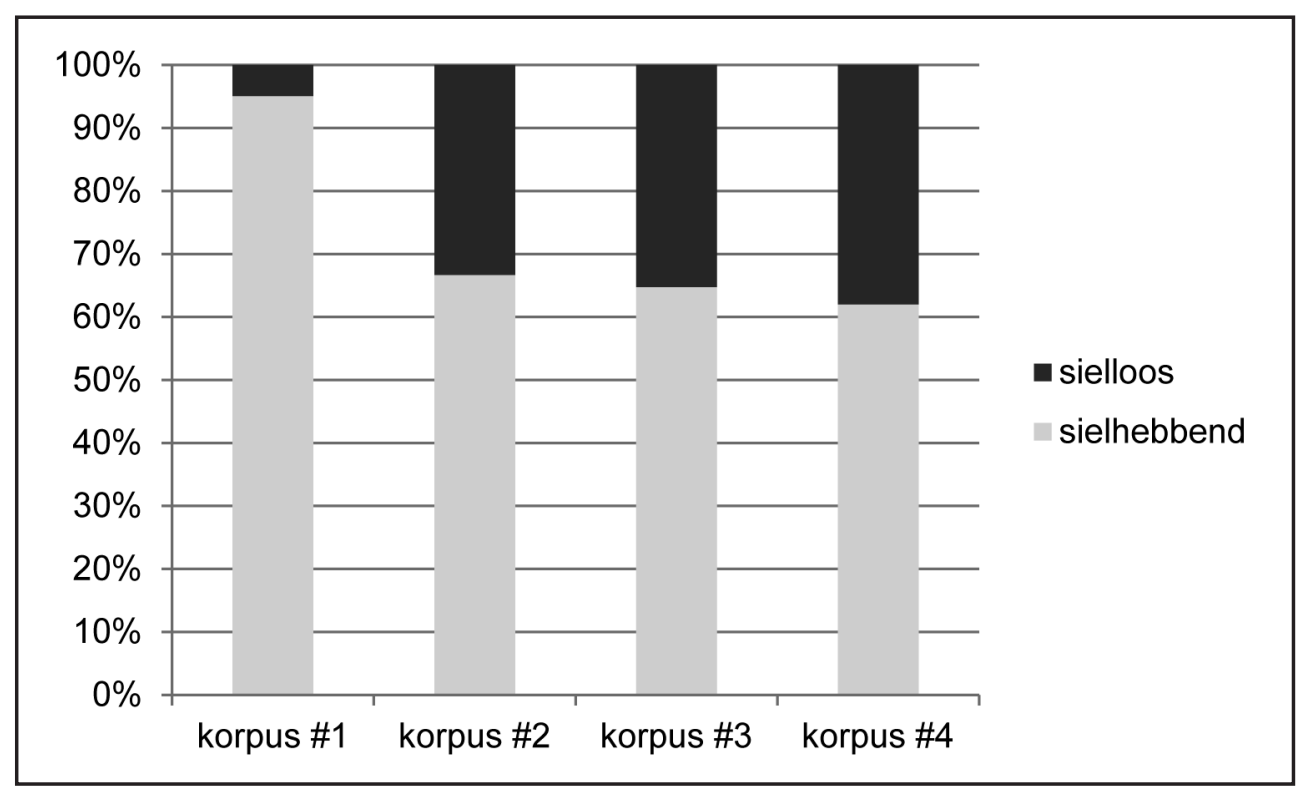

Figuur 7: $\quad$ Tipes sinsonderwerpe wat saam met toekomsverwysende gaan gebruik word

'n Aantal ander gebruikskontekste van Afrikaanse toekomsverwysende gaan kom selde in Standaardnederlands voor (Van Olmen \& Mortelmans 2009:363):

(a) dit kan deur hê (Nederlandse hebben) gevolg word;

(b) dit kan deur wees (Nederlandse zijn) gevolg word;

(c) dit kan deur 'n hoofwerkwoordelike gebruik van gaan gevolg word.

Terwyl nie een van hierdie gebruikskontekste besonder algemeen is nie, is die feit dat dit enigsins voorkom in die klein korpora van hierdie studie steeds veelseggend.

Die proporsionele frekwensies van toekomsverwysende gaan in vergelyking met ander gebruike van gaan, sowel as die verskillende gebruikskontekste van gaan, wys duidelike tekens van voortdurende grammatikalisering. Die afname in gebruiksfrekwensie van episte-

12 Log-waarskynlikheid vir die vier korpora opeenvolgend: 24.67 
miese toekomsverwysende sal wys ook dat gaan besig is om 'n deel van sal se funksies oor te neem.

\section{GEVOLGTREKKING}

Afrikaanse toekomsverwysing wyk nie af van algemener patrone in die Wes-Germaanse taalfamilie nie. Dieselfde gereedskap wat in Nederlands gebruik word, word ook in Afrikaans aangewend (sal, gaan en toekomstige presens), hoewel daar eiesoortige ontwikkelings in Afrikaans plaasgevind het. Veral die beperkings in die gebruik van toekomsverwysende gaan wat in spesifiek Standaardnederlands geld, is nie van toepassing op die gebruik van toekomsverwysende gaan in Standaardafrikaans nie.

'n Sistematiese analise van kontemporêre gesproke data (wat veral ander variëteite as die Standaard insluit) sal 'n sinvolle volgende stap wees in die bestudering en beskrywing van toekomsverwysing in Afrikaans. 'n Meer uitgebreide beskrywing van die gebruik van die toekomstige presens sal ook 'n welkome aanvulling wees.

\section{BIBLIOGRAFIE}

Biber, D., Conrad, S. \& Reppen, R. 1998. Corpus linguistics: Investigating language structure and use. Cambridge: Cambridge University Press.

Carstens, A.1998. Die Afrikaanse medewerkwoorde, familieverwantskappe en grammatikalisering. Suid-Afrikaanse Tydskrif vir Taalkunde, 16(3):73-81.

De Stadler, L.1992. Die werkwoorde kom en gaan as deiktiese medewerkwoorde. Suid-Afrikaanse Tydskrif vir Taalkunde, 10(2):91-98.

Heine, B. 2003. In Joseph \& Jande (reds).The handbook of historical linguistics. Malden, Oxford, Melbourne \& Berlin: Blackwell, pp. 575-601.

Hilpert, M. 2007. Germanic future constructions: A usage-based approach to grammaticalization. Houston: Rice University (Thesis).

Hilpert, M. 2008. Germanic future constructions: A usage-based approach to language change. Amsterdam / Philadelphia: John Benjamins.

Leech, G., Hundt, M., Mair, C. \& Smith, N. 2009. Change in contemporary English: a grammatical study. Cambridge: Cambridge University Press.

Mair, C. 2006. Twentieth-century English: history, variation and standardization. Cambridge: Cambridge University Press.

Müller, D. 2003. Skryf Afrikaans van A tot Z: die essensiële gids vir taalgebruikers. Kaapstad: Pharos Woordeboeke.

Ponelis, F.A. 1979. Afrikaanse sintaksis. Pretoria: Van Schaik.

Poplack, S. \& Tagliamonte, S. 2000. The grammaticization of going to in (African American) English. Language Variation and Change, 11:315-342.

Rayson, P. 2017. Log-likelihood and effect size calculator. Online: ucrel.lancs.ac.uk/llwizard.html [17 Augustus 2017].

Van der Auwera, J. \& Plungian, V.A. 1998. Modality's semantic map. Linguistic Typology, 2:79-124.

Van Olmen, D. \& Mortelmans, T. 2009. In Tsangalidis \& Facchinetti (reds). Studies on English modality. Bern: Peter Lang, pp. 357-386.

Wybenga, D. 1993. Gewete en waargenome wêreld: 'n tekstuele perspektief op Afrikaanse tydsuitdrukking. Suid-Afrikaanse Tydskrif vir Taalkunde, 24(2):15-30. 